\title{
St Apollonia's tooth - a relic in the cathedral treasury in Rab (Croatia)
}

\author{
A. Skrobonja, ${ }^{1}$ V. Rotschild ${ }^{2}$ and T. Culina ${ }^{3}$
}

IN BRIEF

- Presents a virtually unknown relic and explains its importance to Christian and ethnomedical tradition.

- Uses a paleodontological approach in an attempt to scientifically evaluate this relic phenomenon.

Aim To anatomically identify and describe the changes on the tooth of St Apollonia which is kept as a relic in Rab (Croatia). Sources and methods Reviewing relevant literature, macroscopic examination of the tooth in the reliquary, photographing and further examining the enlarged photos. Results The tooth in question is the first upper right premolar. Observed pathological change is type II enamel lesion, ie cervical or gingival caries. Other discovered characteristics are enamel fracture on the distoaproximal surface, shallow fracture on the occlusal third of the crown and two enamel formations, a cluster of smooth and shiny enamel surfaces. Conclusion Attention is drawn to a relic that was previously virtually unknown. It is presented how important this relic is for Christian and ethnomedical tradition. Additionally, anatomical determination and the description of pathoanatomical changes are used to affirm the anthropological approach as one of the prerequisites in the attempt to scientifically evaluate the relic phenomenon.

\section{INTRODUCTION}

Christians have been keeping and venerating relics of their saints since the time of the Roman Catacombs (used c.200-900 $\mathrm{AD})$. Afterwards, this tradition was taken from Rome and spread throughout the entire Christian world. In the expansion of Christianity, graves of the saints became especially appreciated and they also became the object of pilgrimage. However, since for a variety of reasons, especially for Barbarian attacks, the graves outside city walls were commonly difficult to visit, the earthly remains of the saints started to be exhumed and then taken all over Mediaeval Europe, as a whole or in pieces. Thus brought to the cities, the relics were stored in churches which were typically renamed for the purpose, or erected honouring the martyrs whose relics they were proud of. In these transactions fraud often occurred,

\footnotetext{
${ }^{1 *}$ Rijeka University School of Medicine, Department of the History of Medicine, Rijeka, Croatia; ${ }^{2}$ Private dental practice, Rijeka, Croatia; ${ }^{3}$ Teaching Institute for Public Health in Rijeka, Croatia

${ }^{*}$ Correspondence to: Prof. Ante Skrobonja, Rijeka University School of Medicine, Bace Branchetta 20, 51000 Rijeka, Croatia

Email:amteskrobonja@yahoo.com
}

\section{Refereed Paper}

Accepted 25 August 2009

DOI: $10.1038 /$ sj.bdj.2009.1012

${ }^{\bullet}$ British Dental Journal 2009; 207: 499-502 and in 1543 the highest church authorities stipulated that every relic should also have a special seal (autentica)., ${ }^{1,2}$

\section{RELICS OF RIJEKA ARCHDIOCESE IN WESTERN CROATIA}

It came about that most of the relics of Christian saints were gathered and preserved in Rome and other Italian cities. However, even though less known, one of the most abundant parts when it comes to the number of preserved relics and to the tradition of relic venerating is western Croatia, or, to be more exact, Istria and the Kvarner region, ie Rijeka Archdiocese.

Encouraged by this knowledge, the authors pursued relevant bibliographic sources and did fieldwork within a scientific project entitled 'Medical elements in the religious tradition in Rijeka Archdiocese' and determined that the incredible number of 270 relics of various saints and several completely preserved non-decomposed bodies of saints and the blessed are included in the collection of the parish church of St Blaise in Vodnjan.,4 In Buzet there are thirty-something bones of anonymous saints preserved as well as nine named saints. In Rovinj, Bale and Pula three saints are preserved. Various saint relics are still kept in: Porec, Pican, Labin, Umag, St Lovrec and Pazin..$^{5}$ In the
Kvarner region, in Rijeka's Cathedral there is the head and bones of St Viktor, a finger of St Vitus and about ten bones of martyrs, ${ }^{6}$ and in the Sanctuary of the Mother of God at Trsat a reliquary with the powers of 36 saints is kept, among other things. ${ }^{7}$ In Bakar the powers of St Ursula are revered, and in the cathedral in Senj there rests the body of St Formoza with several smaller reliquaries... ${ }^{8}$

Searching thereon in the sacred collection of the Cathedral of Mary's Assumption in the town of Rab on the island of the same name, we have found, in addition to the old church's inventory, several other interesting votive items shaped as human organs (hands, legs, stomach...) and we identified three relics. Apart from the most distinguishing piece, Skull of St Christopher (the town's patron), there is an unidentified femur (it could belong to St Christopher as well) and a reliquary of the Venetian provenance from the sixteenth/ seventeenth century with highly unusual relic, ie the tooth of St Apollonia, which hasn't yet been described nor mentioned in the literature. According to a local priest, we do not know when or how the relic came to Rab, and we weren't able to find the answer in one of the major papers dealing with the history of the town of Rab and the local church. 


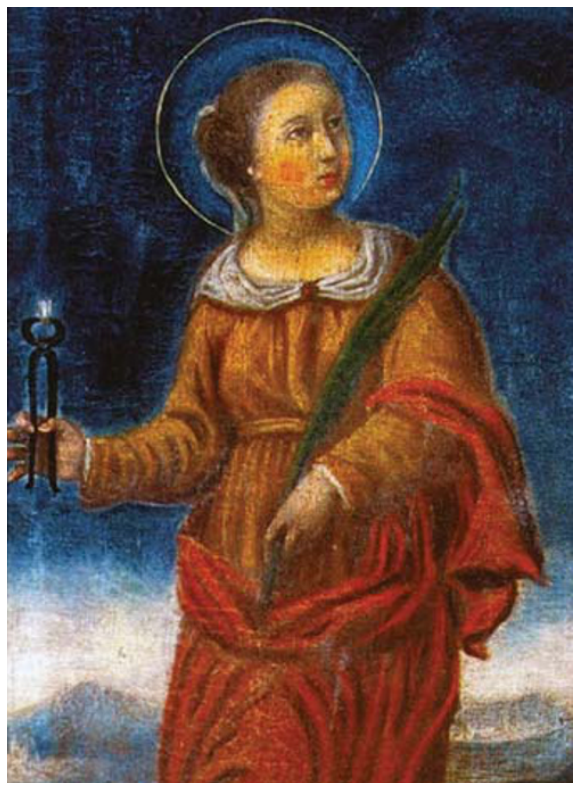

Fig. 1 St Apollonia in a picture from an unknown author from the seventeenth century. The church of St Peter and Paul in Krsete (Istria) (Photo by Ante Skrobonja)

Since unobtrusive and yet visible autentica guarantees that the relic is authentic, and since by careful examination of the literature and the electronic media we were able to find only some 15 relics ascribed to St Apollonia, we determined that this relic deserves not only to be registered but also to be processed from the paleodontological point of view, all the more so because no previously registered case had such description.

Before presenting the tooth itself, let us remind ourselves of the basic hagiographic data on St Apollonia. They will tell us why she arose of teeth and toothache patronage, and why she later became the patron saint of dentists organised in guilds.

\section{A BRIEF BIOGRAPHY OF ST APOLLONIA}

The earliest reliable record of the saintto-be is that of the bishop and historian Eusebius of Caesarea (267-340 AD). This letter describes savage persecutions of Christians during the rule of Emperor Philip the Arab from 244 to $249 \mathrm{AD}$ when most Christians fled Alexandria, save for a few, including the local deaconess Apollonia who preached and converted many to Christianity. According to one legend which draws from this story, the Romans first threatened to burn the girl alive, unless she bowed to heathen idols. As she refused, she was tormented, her face and jaw received heavy blows, and her teeth

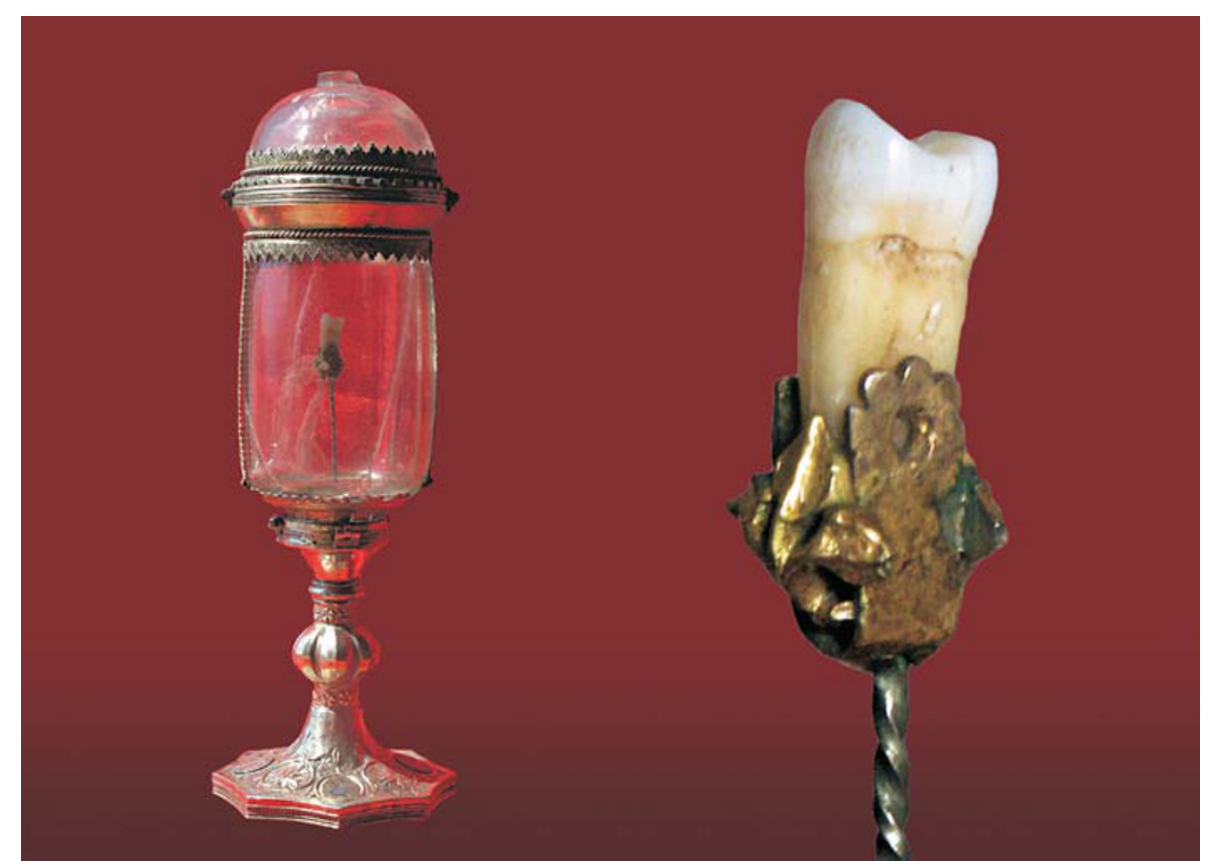

Fig. 2 Reliquary with a tooth of St Apollonia. Treasures of the Cathedral of Assumption of Virgin Mary in Rab. (Photo by Ante Skrobonja)

were pulled out with pincers. According to another legend, all her teeth were broken by fist blows and sharp stones, whereas yet another account refers to decapitation in punishment for having distributed all her family wealth to the poor. Later accounts refer to an infuriated brother who punished his sister for breaking a forced betrothal agreement.

The word of her resolution and courage in sticking to her faith in the face of torture swiftly spread throughout the Christian lands.

In Mediaeval Europe, Apollonia was first worshipped in Flanders and England, then in Spain, Portugal, Italy and other countries. She was canonised by Pope John XXI (1215-1277)..$^{9-11}$

Unlike the legends on early Christian saints such as St Lucy, St Blaise, and St George, taking root among Croats as early as the tenth century, St Apollonia came to these parts from Germany and Bohemia a little later, quite likely in the fifteenth century. Her oldest representations from that period are found in Istria from where they spread to Dalmatia and the rest of Croatia. Most representations of the saint date back to the seventeenth century (Fig. 1). ${ }^{12-13}$

\section{THE TOOTH OF ST APOLLONIA AS A RELIC}

Morphologically, the tooth in question is the first upper premolar (Fig. 2). Topographically, it belongs to the right half of the upper jaw. This is indicated by the characteristic first upper premolar inverted symbol of angle and arch, palatal cusp is lower than buccal cusp, and the chewing surface is kidney-shaped. The root is single-canalled with more pronounced grooves both medially and distally.

On the distal surface of the tooth, in the zone of enamel-cementum junction, below the tooth equator, clinically, we observe type II enamel lesion, cervical or gingival caries, ie smooth approximal surface caries. The caries in question has been arrested. The lesion occurred in a physiologically unclean spot which was cleaned due to the loss of a neighbouring tooth or for some other reason. Demineralisation was stopped, and there are pigment deposits in the damaged spot.

Since St Apollonia was tortured in her youth, the tooth colour and shape can be corroborated by historical data of Dionysius, the Archbishop of Alexandria, who described the persecution of Christianity and the sufferings of 'the beautiful girl of Apollonia'. But, in the circumstances, a full scientific dating of the relic is not possible. Specifically, the enamel on the occlusal edges is bluishwhite. The tooth colour is not considerably different in medial and cervical third due to yellow dentine. The cusps are well pronounced, uneroded, the cementum of the tooth root is yellow. These characteristics are typical for younger people. 
Enamel fracture on the distoapproximal surface indicates traumatic damage. Along with the enamel infraction, on the occlusal third of the crown there is a shallow fracture with pigment deposits.

On the distal surface of the tooth root there are two enamel pearls, a cluster of smooth and shiny enamel surfaces. Incidence of enamel pearls has not been entirely clarified. According to available data these pearls are quite rare.

\section{DISCUSSION}

Aiming to assess the importance of the previously described relic from the cathedral in Rab in the context of other famous relics ascribed to St Apollonia, the authors examined available data from the electronic media, relevant bibliographic references and personal information obtained from the competent persons of the church and revealed that there are 15 relics in Europe and the USA, and there are also several references to questionable relics of St Apollonia being revered.

In one of the oldest attempts to classify the relics of Christian saints, in 1897, William S. Walsh mentioned eight cities and ten churches that hold the relics of St Apollonia. Consequently, in Rome, in the former church of St Apollonia, a major part of her relics was preserved, but evidently, they were distributed to other parts in the meantime. They were probably sent to nearby churches such as Basilica di Santa Maria in Trastevere, where the head of this saint is kept, to Basilica di San Lorenzo fuori le mura, where her arms are kept, and to the church of St Basil, where parts of her jaw are kept. According to Walsh, the other places are: Antwerp (Jesuit church), Brussels (St Augustine's church), Mechlin (Jesuit church), Porto (treasury of the cathedral), several churches in Cologne and an unnamed church in St Cross at Liege. In some cases these relics include only a tooth or a splinter of a bone. ${ }^{14}$

Unfortunately, when we tried to corroborate these statements, we failed to establish a direct contact with these churches and on some of their web pages there was no affirmative data, except in the case of Basilica di Santa Maria in Trastevere. ${ }^{15}$

By researching the Internet further, we found a picture of a golden relic decorated with precious stones depicting a lower molar held in golden pliers, and this relic is kept in the cathedral in Porto, Portugal. ${ }^{16}$

The relics of St Apollonia which couldn't be anatomically defined are further mentioned in one of the largest relic collections, in the renowned cathedral in El Escorial, Spain. ${ }^{17}$

The relics of saints have further been distributed (sold?), which is confirmed by examples from the USA where there are recent references in the chapel of St Mary's College, in St Mary's, Kansas, ${ }^{18}$ and the church of St Joan of Arc, Powell (Ohio). ${ }^{19}$

While it is probable that a lot more relics were preserved in the past, with time they got lost, as is the case with the relics from the church in Auchy-les-Mines in France. After the plague, from 1188 to the Revolution, 1798, there had been pilgrimages organised for the relics of St Apollonia as an acknowledgement of salvation, and thereupon every trace of the relics is lost. ${ }^{20}$

What is most certainly the most spectacular relic-venerating ritual kept to this day is the procession, which has traditionally been held since the ninth century every other Sunday in September, in the old Belgian city of Tournai. On this occasion, 'bras-reliquaire' (hand-reliquaries) with the powers of St Apollonia and several other saints are taken out from the church of St Brice by reconnoiters. ${ }^{21,22}$

In a written announcement by a renowned expert of local church history, Jean-Luc Dubart, a century-old tradition of venerating of St Apollonia is confirmed, both in the city of Tournai, and in the region. According to his findings, in the adjacent Flemish region of Flobecq it is believed that in several churches and chapels there are relics of St Apollonia, which are honoured around 9 February, ie on the day of the saint. On this occasion special thick pancakes are made in the town of Elst. They are called 'Geutelingen', and it is believed that the person chewing these pancakes will be spared toothache. ${ }^{23}$

There is no need to further elaborate on the matter since these illustrations are clear evidence as to how St Apollonia continues to be a part of the Christian and ethnomedical tradition. This saint, by association with the torture she was exposed to, was chosen to be the patron of teeth, a helping hand in toothache, and, subsequently, the patron of dentistry.

\section{CONCLUSION}

The remains of St Apollonia undisputedly deserve our maximum attention since they are relics of the 'first-class', and their value increases because of their rarity.

Two goals have been attained with this presentation. A virtually unknown relic has been presented to the wider public, especially to religious people; and its importance for the Christian and ethnomedical tradition has been pointed out. With the help of a paleodontological approach ie anatomical determination and description of pathoanatomical changes, the anthropological approach has been affirmed as one of the prerequisites in the attempt to scientifically evaluate this relic phenomenon.

The authors would like to give special thanks to Mr Mladen Mrakovcic, the priest from Rab, for his guidance and direct help with researching and photographing the relic as well as with publishing the pictures in this paper.

Big thanks goes to Dr Ado Dorosev, Mrs Catherine Vanden Broecke and Mr Jean-Luc Dubart from Tournai for information on how St Apollonia is honoured in their parts.

This work is part of research within the project by the Ministry of Science and Education of the Republic of Croatia entitled 'Medicinal elements in the religious tradition in Rijeka Archdiocese'.

1. Grgic M. Relics. In Badurina A (ed). Lexicon of iconography, liturgics and symbolism in western Christianity. (In Croatian). Zagreb: Sveucilisna naklada Liber, Krscanska sadasnjost, Institut za povijest umjetnosti, 1990., str. 507-508.

2. Sanders T. Relics. (In Croatian). In Glazier M, Helwig M K (eds). The modern Catholic encyclopedia. Split: Laus, 1998: 833

3. Skrobonja A, Ivinic M. A contribution to anthropological study of the relics of St Sebastian and St Barbara in the church of St Blaise in Vodnjan (Croatia). (In Croatian). Medicus 2006; 15: 345-349.

4. Jelinic M. Gallery of great. (In Croatian). Vodnjan: Zupni ured, 2004.

5. Nezic D. Istrian saints and blessed. (In Croatian). In Badurina A (ed). Lexicon of iconography, liturgics and symbolism in western Christianity. Zagreb: Sveucilisna naklada Liber, Krscanska sadasnjost, Institut za povijest umjetnosti, 1990: 264-267.

6. Balabanic Facini M, Nepokoj D (eds). Glow Jesuit heritage in Rijeka. (In Croatian). Katalogue izlobe. Rijeka: Pomorski i povijesni muzej Hrvatskog primorja, 1993.

7. Hosko E. Reliquary of Barbara Frankopanska (In Croatian). In: Na vrhu trsatskih stuba. Rijeka: Tiskara Rijeka, 1991, 53-56.

8. Razovic M. ur. Guide of the Church in Croatia. (In Croatian). Zagreb: I.t.d. d.o.o., 1996, str.15.

9. Dubart J L. Les saints guérisseurs. pp 78-79. Ath: AB editions, 2002.

10. Hoffman - Axtehelm. Lexicon der Zehnmedicin pp 54-54. Berlin: Quinssenz, 1974.

11. Skrobonja A. Patron Saints of Health. (In Croatian). Zagreb: Krscanska sadasnjost, 2004: 37-38.

12. Kordic S. St Apollonia in Dalmatian Iconography. (In Croatian). Saopcenja 1971; 14: 35-41.

13. Dugacki V, Dorn V. Saint Apollonia Among Croats, Iconography and Folk Lore. (In Croatian). In Vulikic 
V (ed). Cetrti Pintarjevi dnevi. Prof. dr. Joze Rant - Organizatora slovenskega zobozdravstva. pp 171-

175. Ljubljana: Institut za zgodovino medicine, 1996.

14. Walsh W S. Curiosities of popular customs and of rites, ceremonies, observances, and miscellaneous antiquities. 1897.

15. Basilica Santa Maria in Trastevere. Available at: http: //en.wikipedia.org/wiki/Santa_Maria_in_ Trasteverebasilica. Last accessed 20 April 2009

16. Tooth of St Apollonia. Available at: http:// upload.wikimedia.org/wikipedia/commons/c/cb/
Tooth-of-saint-apollonia.jpg. Last accessed 20 April 2009.

17. El Escorial. Available at: <http://es.wikipedia.org/ wiki/Monasterio_de_El_Escorial\#Relicarios $>$. Last accessed 20 April 2009.

18. Rev. Ramon Angles. Written communication, 16 December 1999.

19. St Joan of Arc. Catholic Church, Powell (Ohio). Available at: http://www.stjoanofarcpowell.org/ relics.html Last accessed 20 April 2009.

20. Historique d' Auchy-les-Mines. Available at: http://
auchy.prevert.free.fr/Histoire.htm\#Auchy\%20 au $\% 20$ temps $\% 20$ des $\% 20$ Comtes $\% 20$ de $\% 20$ Flandres Last accessed 20 April 2009

21. The Great Procession of Tournai. Available at: http:// denonne.maluchy.com/typroc/apollo.htm Last accessed 20 April 2009.

22. La grand procession de Tournai. Available at: http:// users.belgacom.net/Grande_Procession_Tournai. Last accessed 20 April 2009.

23. Jean-Luc Dubart. Written communication. 30 January 2008. 